\title{
The Epithelial Sodium Channel ENaC and its Regulators in the Epidermal Permeability Barrier Function
}

\author{
Simona Frateschi ${ }^{1}$, Roch-Philippe Charles ${ }^{1, \#}$ and Edith Hummler ${ }^{*}, 1$ \\ ${ }^{I}$ Département de Pharmacologie et de Toxicologie, University of Lausanne, Rue du Bugnon 27, CH-1005 Lausanne, \\ Switzerland
}

\begin{abstract}
The highly amiloride-sensitive epithelial sodium channel $\mathrm{ENaC}$ is well known to be involved in controlling whole body sodium homeostasis and lung liquid clearance. ENaC expression has also been detected in the skin of amphibians and mammals. Mice lacking ENaC expression lose rapidly weight associated with an epidermal barrier defect that develops following birth. This dehydration is accompanied with a highly abnormal lipid matrix composition and an impaired skin surface acidification. This strongly suggests a role of $\mathrm{ENaC}$ in the maturation of barrier function rather than in the prenatal generation of the barrier, and may be as such an important modulator for skin hydration. In parallel, gene targeting experiments of regulators of $\mathrm{ENaC}$ activity, membrane serine proteases, also termed channel activating proteases, like CAP1/Prss8 and matriptase/MT-SP1 by themselves have been shown to be crucial for the epidermal barrier function. In our review, we mainly focus on the role of $\mathrm{ENaC}$ and its regulators in the skin and discuss their importance in the epidermal permeability barrier function.
\end{abstract}

Keywords: Sodium channel, transmembrane ion flux, regulators or ENaC, serine protease, barrier dysfunction.

\section{INTRODUCTION}

\section{The Barrier Function of the Skin}

The skin barrier protects against extensive water loss in one direction (outward barrier) and against the invasion of harmful substances from the environment (inward barrier). The complex cellular organization in the epidermis, and the way keratinocytes interconnect, contribute to the epidermal permeability barrier. It has been proposed that during phylogenetic evolution, the mammalian skin has developed at least two independent systems for forming an efficient barrier, namely the cornified envelope (a protein-lipid layer) in the stratum granulosum and corneum and the tight junctions in the second last nucleated layer of the stratum granulosum [1].

More than 20 intercellular proteins, connecting adjacent corneocytes, maintain the integrity of the stratum corneum and are directly related to desquamation processes. Thus, concurrently, a series of structural proteins, including involucrin, loricrin and the class of small proline-rich proteins (SPRs) and S100 proteins are synthesized and sequentially cross-linked by transglutaminases to reinforce the cornified envelope just beneath the plasma membrane [2]. There is a functional redundancy, which is mainly due to the overlapping functions of the transglutaminase substrates, like e.g., loricrin and involucrin [3,4]. Evidence that this cornified envelope assembly is necessary for barrier development in skin was obtained from the study of

*Address correspondence to this author at the Département de Pharmacologie et de Toxicologie, Université de Lausanne, Rue du Bugnon 27, CH-1005 Lausanne, Swizerland; Tel: +41-216925357; Fax: +41216925355; E-mail: Edith.Hummler@unil.ch

"Present Address: UCSF Cancer Research Institute, San Francisco, CA, USA transglutaminase 1-deficient mice that lack cornified envelopes resulting in neonatal lethality [5]. Alterations of corneocyte morphology have also been described in mouse models with epidermal permeability barrier defects as, e.g., irregular shaped corneocytes in Klf4 null mice [6], and volume-enlarged corneocytes in serine protease matriptase/ ST14 -/- [7] and CAP1/Prss8 -/- [8] animal models. Barrier lipids are formed in mice only few days before birth [9] and their deficiency in pSAP- and beta-glucocerebrosidase results in disruption of the water permeability barrier and in early death $[10,11]$. Equally, mice with a targeted disruption of the fatty acid transport protein 4 (Fatp 4) showed a disturbed fatty acid composition of epidermal ceramides, despite a normal distribution of tight junction proteins [12]. Thus, mice with impaired skin barrier function either showed a defect in only one system or in the two components of the barrier in parallel. For example, Klf4 knock-out [6] and transgenic mice expressing desmoglein-3 ectopically [13] showed postnatal lethality due to dehydration, whereas layered organization of the keratinocytes was not affected. Mice deficient for the membrane-bound serine protease CAP1/Prss8 showed a defect in the two systems, a disturbed stratum corneum lipid composition as well as functionally defective tight junctions [8], whereas mice deficient for the tight junction protein claudin-1 exhibited only a defect in the tight junctions [14]. This underlies the importance that both systems are needed and might work concurrently. Equally important is the natural moisturizing factor composed of amino acids and their derivatives, such as pyrrolidone carboxylic acid, together with lactate, sugars and urea and act as efficient humectants to maintain free water in the stratum corneum [15]. The natural moisturizing factor is derived from filaggrin, synthesized in the granular layer as profilaggrin, a large histidine-rich and heavily phosphorylated protein that functions to aggregate keratins. At the transition between the granular layer and the stratum 
corneum, filaggrin is subjected to further modifications through protein phosphatase PP2A and at least three different proteases, including profilaggrin proteinase 1, calpain and furin, resulting in filaggrin peptides of $27 \mathrm{kDa}$ in mice. Proteolyzed into free amino acids, these are thought to provide high osmolarity necessary for the retention of water and maintenance of tissue flexibility. Not surprisingly, mouse models with defect in filaggrin gene (flaky tail, $\mathrm{ft}$ ) [16] exhibit severe impaired epidermal barrier function. Additionally, animal models of caspase-14 [17], involucrin, envoplakin, periplakin [18], lipoxygenases [19] and of serine proteases discussed later in this review, display defective filaggrin processing and impaired epidermal permeability.

The major lipid classes in the stratum corneum are ceramides, free fatty acids and cholesterol. Ceramides are amide-linked fatty acids containing a long-chain amino alcohol called sphingoid base and account for 30 to $40 \%$ of stratum corneum lipids. Ceramides are generated by serinepalmitoyl transferase as rate-limiting enzyme and by hydrolysis of both glucosylceramide through beta-glucocerebrosidase and sphingomyelin through acid sphingomyelinase. The stratum corneum contains at least nine different free ceramides, covalently bound to cornified envelope proteins, e.g., involucrin $[20,21]$. The epidermis contains free fatty acids as well as fatty acids bound in triglycerides, phospholipids, glycosylceramides and ceramides. Cholesterol is the third major lipid class in the stratum corneum. Although basal cells are capable of reabsorbing cholesterol from circulation, most cholesterol in the epidermis is synthesized in situ from acetate. Cholesterol levels are regulated by the membrane transporter ATP-binding cassette subgroup 1 member 12 transporter (ABCA12), responsible for cholesterol efflux, liver $\mathrm{X}$ receptor activators and peroxisome proliferator-activated receptors [12].

Tight junctions are cell-cell junctions connecting neighboring cells, controlling the paracellular pathway of molecules (barrier function) and separating the apical from the basolateral part of a cell membrane (fence function). In human epidermis, various tight junction proteins have been identified, including occludin, claudins 1,4 , and 7, JAM-1 (junctional adhesion molecule-1), ZO-1 (zonula occludens protein 1) and MUPP-1 (multi-PDZ protein-1) [22]. During epidermal re-generation, the synthesis of tight junction proteins precedes the formation of the stratum corneum [23]. Therefore, beside barrier and fence functions, tight junctions have been proposed to present a rescue system when epidermal barrier is perturbed, challenged or absent.

At birth, the epidermal barrier is normally formed consisting of the cornified envelope [24] that develops during the late stages of embryonic life [25]. Yet, it is known that a postnatal maturation of the skin exists as the skin surface $\mathrm{pH}$ is near neutral in humans [26-28] and rodents $[29,30]$ to reach more acidified levels after 10 days (human) [31] and in 7 days (rat) [32] and 2 days (mice) [33]. Thus, in human infants, the delay in acidification could explain the increased infantile risk for irritant/allergic contact dermatitis, infection, and cutaneous absorption of toxic chemicals [27]. Defects in acidification may lead to increased water loss [29] and delayed epidermal permeability barrier recovery [34] explained by the impairment of sphingomyelinase and betaglucocerebrosidase $[21,35]$. Acidification is defective in the sodium/hydrogen antiporter-1 knock-out mice [32, 34, 36] and in the phospholipase $\mathrm{A}_{2}$-deficient mice [37]. Mice overexpressing the $\mathrm{Ca}^{2+}$ receptor showed an accelerated barrier function with a strong hyperkeratosis with increase of inositol-3-phosphate (IP3) [38]. Thus beyond the genes that are clearly known to be crucial for the prenatal barrier formation, there are genes/processes that are rather important for the postnatal maturation of the skin barrier function (e.g. $\mathrm{ENaC}$ and its regulator the membrane-bound serine protease CAP1/Prss8).

\section{Barrier Dysfunctions in Skin Diseases}

Several skin diseases are known to show defects in epidermal permeability barrier function. The most classical ones include atopic dermatitis and psoriasis, although the majority of the studies on the pathogenesis of atopic dermatitis and psoriasis concentrate on the primary role of the immune system abnormalities [39, 40]. However, it is still not clear whether permeability barrier defect is a cause or consequence of inflammation. Atopic dermatitis is characterized by chronic, pruritic, inflammatory dermatosis and the impaired barrier function is most likely caused by increased epidermal proliferation and disturbed differentiation, including changes in lipid composition [41, 42]. Lossof-function genetic variants in the gene encoding filaggrin have been shown to be strong predisposing factors for atopic dermatitis [43]. In psoriasis, the level of transepidermal water loss is directly related to the clinical severity of the lesion [44]. The mode of inheritance of psoriasis is complex; classic genome-wide linkage analysis has identified at least nine chromosomal loci with statistically significant linkage to psoriasis, comprehending genes involved in immune functions and epidermal differentiation [45].

A disturbed skin barrier is relevant for the pathogenesis of ichthyoses, which involve several generalized genetic skin disorders. All types of ichthyosis exhibit dry, thickened, scaly skin. The severity of symptoms can greatly vary, from mild types as ichthyosis vulgaris, up to life-threatening conditions such as harlequin-type ichthyosis. Aberrant filaggrin expression has been found in ichthyosis vulgaris [46]. Several ichthyoses are associated with inherited disorders of lipid metabolism. Mutations in transglutaminase-1 and deficiency in the enzyme steroid sulfatase have been found defective in lamellar ichthyosis and recessive X-linked lamellar ichthyosis, respectively [47, 48]. Lamellar ichthyosis type 2 (LI2) and the harlequin fetus type of congenital ichthyosis are linked to mutations in ATPbinding cassette subgroup 1 member 12 transporter (ABCA12), a membrane transporter responsible for cholesterol efflux [49, 50].

Epithelial barrier function has emerged as a critical factor in the development and progression of allergic diseases. Importantly, patients with atopic dermatitis manifest compromised skin barrier associated with increased allergen sensitization that can augment the atopic inflammatory response [51]. This suggests a more global mechanism by which allergen sensitization could contribute to skin inflammation. Even though the epithelium was initially considered to function just as a physical barrier, it is now seen as a central player in sensitization processes. Allergens often interfere directly or indirectly with the innate immune 
functions of airway epithelial cells and dendritic cells of the skin [52].

\section{$\mathrm{ENaC}$ and its Role in the Epidermal Barrier Function}

The non-voltage gated, highly amiloride-sensitive epithelial sodium channel $(\mathrm{ENaC})$ has been extensively studied as a key regulator for sodium homeostasis [53, 54]. $\mathrm{ENaC}$ belongs to a gene family called $\mathrm{ENaC} /$ degenerin (DEG) encoding the $\mathrm{ENaC} \alpha-, \beta-, \gamma-$ (rodents and human) and $\delta$-subunits (humans) [55]. The $\delta$-ENaC isoform can substitute the $\alpha$-ENaC subunit, but is often found in organs distinct from the classical sodium absorbing epithelia [56]. Each subunit has two hydrophobic domains, corresponding to two transmembrane domains, TM1 and TM2, a large extracellular loop making more than one-half of the channel protein representing a structural feature unique to the $\mathrm{ENaC} / \mathrm{DEG}$ family members with short cytoplasmic $\mathrm{N}-$ and C-termini [57, 58]. Electrophysiological characteristics of $\mathrm{ENaC}$ include a high sensitivity to the potassium-sparing diuretic amiloride $\left(\mathrm{K}_{\mathrm{i}} 0.1 \mu \mathrm{M}\right)$, a low conductance of about 5 pS [58], long opened and closed times (0.5-5 s), and a high selectivity for sodium over potassium (> 100:1) [55]. ENaC activity at the organ level seems regulated by the presence or absence of the channel at the membrane, and steroid hormones, like aldosterone or glucocorticoids, and membrane-bound serine protease (see for review [53]).

$\mathrm{ENaC}$ subunits are also expressed in the tongue where have been shown to be implicated in salt tasting [59,60], in the inner ear [61] or the retina function [62]. The presence of an amiloride-sensitive current in the skin of amphibians is known since decades now [63-65]. The movements of ions and their distribution can lead to the formation of an electrical potential. The presence of a negative potential difference has been shown in skin [66]. This potential was impaired if treated with various channel blockers like ouabain $(\mathrm{Na} / \mathrm{K}$ ATPase blocker) or L-type calcium channel blocker like verapamil, and nifedipin [67]. Thus, ENaC activity may play a role in the regulation of diverse cellular processes in the skin like e.g. barrier function, galvanotaxis and wound healing [68].

Different mouse lines have been established in which the $\mathrm{ENaC}$ activity has been altered, and genes encoding for

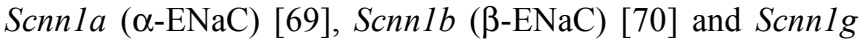
$(\gamma-\mathrm{ENaC})[71]$ have been inactivated. The phenotypes observed in these mice demonstrate that each subunit is essential for survival and for regulation of sodium transport [72-75]. Inactivation of the $\beta$ - and $\gamma$-ENaC subunit led to reduced $\mathrm{ENaC}$ activity, whereas gene targeting of the $\alpha$ $\mathrm{ENaC}$ subunit resulted in completely abolished $\mathrm{ENaC}$ activity [53]. The presence of all three subunits of $\mathrm{ENaC}$ has been demonstrated in the epidermis of mouse, human and rat but also in hair follicles and in sweat glands (humans) [76, 77]. Moreover the expression of $\mathrm{ENaC}$ seems to increase with differentiation of the keratinocytes [78]. Patch clamp recordings on human keratinocytes reveal a sodium channel conductance that is blocked by benzamil with similar affinity and voltage dependence of the amiloride block as previously described for $\mathrm{ENaC}$ [78]. Further evidence that ENaCmediated $\mathrm{Na}^{+}$transport may be implicated in keratinocyte and epidermal differentiation comes from the previous analysis of newborn $\alpha$-ENaC knock-out mice which exhibit epidermal thickening and premature lipid secretion in the upper epidermis, suggesting that $\mathrm{ENaC}$-mediated sodium ion fluxes control selective aspects of keratinocyte differentiation [79]. Gene inactivation of the alpha subunit of the highly amiloride-sensitive epithelial sodium channel $(\alpha-$ $\mathrm{ENaC}$, Scnnla) leads to distinct perinatal effects on epidermal development and homeostasis, which culminates in a barrier defect within the first $24 \mathrm{~h}$, characterized by a loss of body weight (by $6 \%$ in 6 hours) and an increased transepidermal water loss, which is accompanied by a higher skin surface $\mathrm{pH}$ in one day-old pups [33]. While early and late differentiation markers, as well as tight junction protein distribution and function seem not affected, deficiency of $\alpha$ $\mathrm{ENaC}$ severely disturbs the stratum corneum lipid composition with decreased ceramide and cholesterol levels, and increased pro-barrier lipids glucosylceramide, sphingomyelin and cholesterol sulfate, while covalentlybound ceramide and $\omega$-hydroxylated fatty acid are drastically reduced. Ultra-structural analysis revealed morphological changes in the formation of intercellular lamellar lipids and the lamellar body secretion. Extracellular formation of the lamellar lipids proved to be abnormal in the knock-outs. In conclusion, ENaC-deficiency results in progressive dehydration and consequently weight loss due to severe impairment of lipid formation and secretion (Table 1). Our data further demonstrate that $\mathrm{ENaC}$ expression is required for the postnatal maintenance of the epidermal barrier function, but not for its generation.

Transmembrane ionic fluxes are controlling keratinocyte differentiation and the synthesis of cornified envelope and other differentiation-specific proteins, conversion of profilaggrin to filaggrin and secretion of stratum corneum lipid precursors [80]. Further evidence that ions may be important regulators in these processes is suggested by the presence of a calcium gradient within the epidermis, with higher quantities of $\mathrm{Ca}^{2+}$ in the upper than in the lower epidermis [81]. Moreover, $\mathrm{Na}^{+}$influx also modulates $\mathrm{Ca}^{2+}-$ induced keratinocyte differentiation. Thus, application of amiloride, the known inhibitor of $\mathrm{ENaC}$, blocks $\mathrm{Ca}^{2+}-$ induced differentiation in keratinocytes. Only recently, mice deficient for ion/water channels and transporters are analyzed for their skin phenotype. Keratinocytes from mice deficient for the $\mathrm{Ca}^{2+}$-sensing receptor did no longer respond to extracellular $\mathrm{Ca}^{2+}$, and the mice exhibit disordered differentiation [82]. Mice deficient for the sodium channel $\mathrm{ENaC}$ show severe dehydration and mice lacking the NHE1 exchanger exhibit an impaired stratum corneum acidification $[29,34]$. The water transporting protein aquaporin-3 functions as a glycerol transporter in mammalian skin and mice deficient in AQP3 exhibit dry skin with reduced stratum corneum hydration, decreased elasticity and impaired biosynthesis $[83,84]$. In human, mutations in the different subunits of the channel are the cause of human hereditary diseases [85]. Hereditary mutations of $\mathrm{ENaC}$ subunits have been described leading to disturbed sodium homeostasis. First, in the Liddle's syndrome, the C-terminal tail of $\beta$ or $\gamma$ is mutated in the proline-rich domain, preventing ubiquitination by Nedd4-2 then causing hypertension and hypokaliemia due to the higher availability of $\mathrm{ENaC}$ at the membrane [53, 54]. Second, the pseudohypoaldosteronism type I (PHA-1), characterized by a decreased $\mathrm{ENaC}$ activity resulting in salt wasting and 
Table 1. Comparative Phenotypes of ENaC, CAP1/Prss8 and CAP3/Tmprss14 Mouse Models

\begin{tabular}{|c||c|c|c|c|}
\hline & $\begin{array}{c}\text { Complete Alpha ENaC } \\
\text { Knock-Out }\end{array}$ & $\begin{array}{c}\text { Skin-Specific } \\
\text { CAP1/Prss8 } \\
\text { Knock-Out }\end{array}$ & $\begin{array}{c}\text { Complete } \\
\text { CAP3/Tmprss14 } \\
\text { Knock-Out }\end{array}$ & $\begin{array}{c}\text { Transgenic CAP3/Tmprss14 } \\
\text { (K5 Promoter) }\end{array}$ \\
\hline \hline Epidermal Features & hyperplasia & hyperkeratosis & hyperkeratosis & hyperplasia, tumor formations \\
\hline Barrier Function & impaired & impaired & impaired & n.d. \\
\hline Differentiation Markers & K6 over-expression & filaggrin processing defect & filaggrin processing defect & K6 over-expression \\
\hline Tight Junctions & functional & Severely impaired & n.d. & n.d. \\
\hline Lipid Composition & severely affected & affected & affected & n.d. \\
\hline References & {$[79,33]$} & {$[8]$} & [7, 109] & [117] \\
\hline n.d. = not determined. & & &
\end{tabular}

hypotension, is due to mutations leading to expression of inefficient forms of the three subunits [75]. In PHA-1 patients carrying ENaC-mutations, macroscopic skin lesions like dermatitis have been described, although the skin phenotype was not further analyzed. Thus, it is still unknown whether dysfunction of $\mathrm{ENaC}$ channels in skin contributes to and/or is indeed causative for defined skin diseases [68].

\section{ENaC Regulators in the Epidermal Permeability Barrier Function}

To detect proteins involved in $\mathrm{ENaC}$ regulation, Vallet and colleagues screened a Xenopus A6 cell complementary DNA library allowing the isolation of a serine protease whose co-expression with $\mathrm{ENaC}$ induced a 3-fold increase in the $\mathrm{ENaC}$ sodium current [86]. Consequently, this serine protease was termed Xenopus channel-activating protease-1 (xCAP1), encoded by $\operatorname{Prss} 8$ gene and ortologous to human prostasin, that presents a glycosyl-phosphatidyl-inositol (GPI)-anchored protein [86]. Two years thereafter, the mouse counterpart was cloned in a cortical collecting duct cell line derived from mouse kidney and identified as mouse CAP1 (mCAP1) [87]. CAP1/Prss8 appeared to be coexpressed in epithelial tissues with $\mathrm{ENaC}$ such as kidney, lung, colon, skin, ovary and salivary glands [86, 87]. CAP1/Prss 8 is produced as zymogen and in vitro experiments indicated its inability to auto-activate, suggesting that its proteolytic activity is regulated by an upstream protease. Accordingly, no evidence of CAP1/Prss8 intramolecular cleavage was seen in vitro experiments in Xenopus oocytes [88, 89]. Hypertension and elevated levels of urinary CAP1/Prss8 have been reported in rats transiently over-expressing CAP1/Prss8 [90]. Increased urinary CAP1/Prss8 excretion also occurs in patients with hypertension from primary hyperaldosteronism and is stimulated by saline infusion or mineralcorticoids [91, 92]. CAP1/Prss8 is highly expressed in cystic fibrosis airways and it is a strong basal activator of $\mathrm{ENaC}$ in cystic fibrosis airway epithelial cells $[93,94]$. These observations predict that CAP1/Prss8 has a critical role in regulating epithelial sodium transport in normal and pathological conditions. On the other hand, CAP1/Prss8 is down-regulated in hormone refractory prostate cancers, gastric and breast cancer [95-98] and it has been found over-expressed in epithelial ovarian cancer [99] suggesting an additional role of CAP1/Prss 8 in tumor invasion. Carattino et al. claim that proteolytic processing of $\mathrm{ENaC}$ gamma subunit by CAP1/Prss8 has a dominant role in $\mathrm{ENaC}$ activation [100]. In contrast,
Andreasen and colleagues have shown that catalytically inactive CAP1/Prss8 is still able to fully activate ENaC [89]. To ascertain the role of mCAP1 in the different tissues, an allelic series of mutations at the mouse Prss 8 gene locus were generated to delete its vital region (exon 3, 4 and 5) in a temporally and/or tissue-specific manner [101]. These animals allowed studying the consequences of CAP1/Prss 8 deficiency in epidermal function by crossing them with keratin-14 Cre-recombinase transgenic mice [102]. Mice lacking CAP1/Prss8 in skin died 60 hours after birth [8]. A member of the epidermal proteins, the lipid constituent of the cornified envelope and the tight junction functionality were found defective in skin-specific CAP1/Prss8 knock-out mice, indicating that each component of the epidermal permeability barrier suffered from the lack of CAP1/Prss8 in the skin. The epidermis lacking CAP1/Prss 8 presented an aberrant pattern of profilaggrin-derived proteolytic products, with nearly complete loss of filaggrin monomers. Corneocytes morphogenesis was perturbed and the level of pro-barrier and covalently bound lipids was altered in CAP1/Prss8-deficient epidermis. No expression of occludin was found in the CAP1/Prss8-deficient skin and the tight junction functionality, at least against molecules of about 600 Dalton, was severely affected. These defects can be causative of a more reddish and wrinkled skin evident few hours after birth, a hyperkeratotic stratum corneum and incompletely matured and reduced in number hair follicles and a severe impairment of both inward and outward barrier functions of the epidermis, which most likely lead to early postnatal death in mice lacking CAP1/Prss8 in the skin [8].

The ENaC-mediated sodium current, measured in the mouse cortical collecting duct cell line, from which mCAP1 was identified, appeared to be only $50 \%$ sensitive to the serine protease inhibitor aprotinin [87]. This suggested that $\mathrm{ENaC}$ activation depends on more than one serine protease with different sensitivity to aprotinin, and lead to the discovery of two additional membrane-bound serine proteases found to increase 6 to 10 -fold $\mathrm{ENaC}$ currents [87]. Accordingly, these serine proteases were called mCAP2 and mCAP3. mCAP2 is a type II-oriented membrane-bound serine protease whom protease domain shares homology with xCAP1 (45\%), mCAP1 (43\%), and 80\% with the human orthologue hTMPRSS4 [103]. CAP2/Tmprss4 requires catalytic activity to activate $\mathrm{ENaC}[89,104]$ and it has been reported that $\mathrm{CAP} 2$ cleaves all three $\mathrm{ENaC}$ subunits, both with and without associated stimulation [104]. CAP2/Tmprss4 appeared to be highly expressed in lung 
cancer tissues compared with normal tissues and was found to be broadly expressed in a variety of human cancer cell lines, resulting in an important mediator of invasion, metastasis, migration and adhesion [105]. However, the physiological functions of CAP2/Tmprss4 remain to be ascertained in the whole organism by, e.g., conditional gene targeting models.

mCAP3 is identical to the mouse epithin/Tmprss14 [106]. As CAP2/Tmprss4, CAP3/Tmprss14 is a type II serine protease which shares $47 \%$ homology with the mouse trypsinogen, $49 \%$ with xCAP1, 40\% with mCAP2 and $83 \%$ with the human orthologue hMT-SP1 [107] also known as matriptase [108]. CAP3/Tmprss14 has an essential physiological role in profilaggrin processing, corneocyte maturation, and lipid matrix formation associated with terminal differentiation of the oral epithelium and the epidermis, and is also critical for hair follicle growth. In mice, targeted ablation of the serine protease CAP3/Tmprss14 leads to postnatal lethality within 48 hours, striking malformation of the stratum corneum, seriously compromised epidermal barrier function and loss of proteolytically processed filaggrin [7]. Interestingly, complete CAP3/Tmprss14 and skin specific CAP1/Prss8 knock-out mice exhibit similar phenotypes ([7, 8, 109] and Table 1) and it has been proposed that CAP $1 / \operatorname{Prss} 8$ presents the downstream substrate target of CAP3/Tmprss14 [110]. However, mice constitutively lacking CAP1/Prss8 are embryonic lethal (R.-P. Charles and E. Hummler manuscript in preparation), whereas mice deficient for matriptase/MTSP1 go through the embryonic development and die after birth indicating that these serine protease might exhibit tissue/organ-specific roles independent from each other [7]. Despite the known structural (e.g. epidermal thickness) and functional (e.g. sweet gland) differences between mouse and human skin, the human skin disease the autosomal recessive ichthyosis with hypotrichosis, found to be caused by mutation in CAP3/Tmprss14 gene [111], shows close similarity with the CAP3/Tmprss 14 deficiency in mouse skin [112]. CAP3/Tmprss14 is an efficient activator of prourokinase plasminogen activator (pro-uPA), hepatocyte growth factor/scatter factor (HGF/SF), and PAR2 in vitro, and CAP3/Tmprss 14 could have pleiotropic functions in the activation of proteolytic cascades, growth factors, and $\mathrm{G}$ protein coupled receptors [113]. CAP3/Tmprss14 is universally co-expressed with its cognate inhibitor, hepatocyte growth factor activator inhibitor-1 (HAI-1) encoded by the serine protease inhibitor Kunitz type 1 (Spint1), in both normal and malignant tissues [114-116]. Modest CAP3/Tmprss14 orthotopic over-expression in the skin of transgenic mice caused spontaneous squamous cell carcinoma and dramatically potentiated carcinogen-induced tumor formation (Table 1). Increasing epidermal HAI1/Spint1 expression completely negated CAP3/Tmprss14 oncogenic effects [117]. HAI-1/Spint1 is a membrane-bound serine proteases inhibitor expressed in various epithelial tissues, such as the gastrointestinal tract, breast, prostate, lung and skin [118]. Several in vitro studies showed that HAI-1/Spint1 potently inhibits trypsin-like serine proteases such as hepatocyte growth factor activator, CAP3/Tmprss14, hepsin/Tmprss1, and CAP1/Prss8 [119-123]. Homozygous deletion of HAI-1/Spint1 in mice resulted in embryonic lethality attributable to impaired placental development
[124]. High chimeric HAI-1/Spint1 knock-out newborns showed growth retardation and died by 16 days. These mice developed scaly skin because of hyperkeratinization, reminiscent of ichthyosis, and abnormal hair shafts that showed loss of regular cuticular septation. The interfollicular epidermis showed acanthosis and immunoblot analysis revealed altered proteolytic processing of profilaggrin in HAI-1/Spint1 deleted skin with impaired generation of filaggrin monomers [125] indicating an important role of this serine protease inhibitor for skin patho-physiology.

Defective $\mathrm{ENaC}$ processing and function has been observed in tissue kallikrein-deficient mice [126]. Tissue kallikreins are extracellular serine proteases secreted by keratinocytes into upper stratum granulosum and stratum corneum interstices of the epidermis and are also localized in appendages such as hair follicles and sweat glands [127129]. The proteolytic activity of kallikreins is regulated in several ways including zymogen activation, endogenous inhibitors, such as serpins, and via internal (auto) cleavage leading to inactivation. Until recently, kallikrein proteolytic activity in the skin was exclusively ascribed to kallikrein-5 and kallikrein-7 (also known as stratum corneum tryptic enzyme, SCTE, and stratum corneum chymotryptic enzyme, SCCE, respectively) even though other kallikreins are expressed in the skin and its associated appendages [130] that show involvement in skin barrier functions [131]. It has been found increased epidermal expression of SCCE in psoriasis and in atopic dermatitis patients. Transgenic mice expressing SCCE in suprabasal epidermal keratinocytes develop pathologic skin changes with increased epidermal thickness, hyperkeratosis, dermal inflammation, and severe pruritus [132]. The activities of SCTE and SCCE are increased in SPINK5 (serine protease inhibitor Kazal-type 5, encoding the putative multi-domain serine protease inhibitor LEKTI) deficient mice, and these mice mimic the epidermal dysfunctions in human disease Netherton syndrome leading to a disruption in skin barrier function [133].

It has been recently found that the purified serine protease plasmin from nephrotic urine activates the epithelial sodium channel $\mathrm{ENaC} \mathrm{[134]} \mathrm{and} \mathrm{that} \mathrm{plasmin} \mathrm{activates}$ $\mathrm{ENaC}$ in association with inducing cleavage of the gammasubunit [135]. Plasminogen is a zymogen that is converted to the active enzyme plasmin by tissue plasminogen activator, urokinase plasminogen activator and factor XII [136]. However plasmin has been proposed as one of the main extracellular and cell surface proteases involved in wound healing [137] and its activity has been found significantly increased after disruption of the epidermal barrier [138] indicating additional $\mathrm{ENaC}$ regulators implicated in skin barrier function.

\section{CONCLUSIONS AND PERSPECTIVES}

In conclusion, our recent results unveil the physiological consequences in skin of the highly amiloride-sensitive epithelial sodium channel deficiency that leads to distinct phenotypes in the prenatal versus the postnatal period. We propose that $\mathrm{ENaC}$ plays an important role in the maintenance of the postnatal epidermal barrier function. The fine tuning between activation and inhibition of serine proteases, which present regulators of $\mathrm{ENaC}$, appear to play a key role in epidermal homeostasis [139]. These serine 
proteases are known to be deregulated during tissue damage and thereby contribute to injury, repair, and cell survival responses, although the in vivo molecular targets of these membrane-bound serine proteases are largely unknown. The cellular actions of these serine proteases may be mediated through activation of G-protein-coupled receptors like the protease-activated receptors (PARs), and regulated by serine protease inhibitors and associated proteins. It will be important to identify the remaining members of these cascades, as well as the signals that trigger their activation. This delicate balance can be disturbed by genetic defects or exogenous influences and has been shown as the underlying and promoting cause for a large number of different diseases. Abnormalities in skin-specific knock-outs of these serine proteases and its comparison with $\mathrm{ENaC}$-deficient mutant mice will give new insights into molecular mechanisms of the epidermal permeability barrier function, its implication in genetic disorders, and the identification of putative target proteins. Recently, we could demonstrate in vivo a crucial role of CAP1/Prss8 in the regulation of $\mathrm{ENaC}$ in the lung being implicated in ENaC-mediated alveolar sodium and water transport and fluid balance [140]. Thus, a better understanding of these interactions, ascertained from animal and human studies will help to develop novel means of prevention and treatment.

\section{ACKNOWLEDGEMENTS}

Thanks to all members of the laboratory for contributing to the research projects. Work in the laboratory of EH is supported by grants from the Swiss National Science Foundation.

\section{REFERENCES}

[1] Tsuruta D, Green KJ, Getsios S, Jones JC. The barrier function of skin: how to keep a tight lid on water loss. Trends Cell Biol 2002; 12(8): 355-7.

[2] Candi E, Schmidt R, Melino G. The cornified envelope: a model of cell death in the skin. Nat Rev Mol Cell Biol 2005; 6(4): 328-40.

[3] Djian P, Easley K, Green H. Targeted ablation of the murine involucrin gene. J Cell Biol 2000; 151(2): 381-8.

[4] Koch PJ, de Viragh PA, Scharer E, et al. Lessons from loricrindeficient mice: compensatory mechanisms maintaining skin barrier function in the absence of a major cornified envelope protein. $\mathbf{J}$ Cell Biol 2000; 151(2): 389-400.

[5] Matsuki M, Yamashita F, Ishida-Yamamoto A, et al. Defective stratum corneum and early neonatal death in mice lacking the gene for transglutaminase 1 (keratinocyte transglutaminase). Proceedings of the National Academy of Sciences of the United States of America. 1998; 95(3):1044-9.

[6] Segre JA, Bauer C, Fuchs E. Klf4 is a transcription factor required for establishing the barrier function of the skin. Nat Genet 1999; 22(4): 356-60.

[7] List K, Haudenschild CC, Szabo R, et al. Matriptase/MT-SP1 is required for postnatal survival, epidermal barrier function, hair follicle development, and thymic homeostasis. Oncogene 2002; 21(23): 3765-79.

[8] Leyvraz C, Charles RP, Rubera I, et al. The epidermal barrier function is dependent on the serine protease CAP1/Prss8. J Cell Biol 2005; 170(3): 487-96.

[9] Doering T, Brade H, Sandhoff K. Sphingolipid metabolism during epidermal barrier development in mice. J Lipid Res 2002; 43(10): 1727-33.

[10] Doering T, Holleran WM, Potratz A, et al. Sphingolipid activator proteins are required for epidermal permeability barrier formation. J Biol Chem 1999; 274(16): 11038-45.

[11] Doering T, Proia RL, Sandhoff K. Accumulation of protein-bound epidermal glucosylceramides in beta-glucocerebrosidase deficient type 2 Gaucher mice. FEBS Lett 1999; 447(2-3): 167-70.
[12] Herrmann T, van der Hoeven F, Grone HJ, et al. Mice with targeted disruption of the fatty acid transport protein 4 (Fatp 4, Slc27a4) gene show features of lethal restrictive dermopathy. J Cell Biol 2003; 161(6): 1105-15.

[13] Elias PM, Matsuyoshi N, Wu H, et al. Desmoglein isoform distribution affects stratum corneum structure and function. J Cell Biol 2001; 153(2): 243-9.

[14] Furuse M, Hata M, Furuse K, et al. Claudin-based tight junctions are crucial for the mammalian epidermal barrier: a lesson from claudin-1-deficient mice. J Cell Biol 2002; 156(6): 1099-111.

[15] Rawlings ND, Tolle DP, Barrett AJ. Evolutionary families of peptidase inhibitors. Biochem J 2004; 378(Pt 3): 705-16.

[16] Presland RB, Boggess D, Lewis SP, Hull C, Fleckman P, Sundberg JP. Loss of normal profilaggrin and filaggrin in flaky tail (ft//ft) mice: an animal model for the filaggrin-deficient skin disease ichthyosis vulgaris. J Invest Dermatol 2000; 115(6): 1072-81.

[17] Denecker G, Hoste E, Gilbert B, et al. Caspase-14 protects against epidermal UVB photodamage and water loss. Nat Cell Biol 2007; 9(6): 666-74

[18] Sevilla LM, Nachat R, Groot KR, et al. Mice deficient in involucrin, envoplakin, and periplakin have a defective epidermal barrier. J Cell Biol 2007; 179(7): 1599-612.

[19] Epp N, Furstenberger G, Muller K, et al. 12R-lipoxygenase deficiency disrupts epidermal barrier function. J Cell Biol 2007; 177(1): 173-82.

[20] Holleran WM, Takagi Y, Menon GK, Legler G, Feingold KR, Elias PM. Processing of epidermal glucosylceramides is required for optimal mammalian cutaneous permeability barrier function. J Clin Invest 1993; 91(4): 1656-64.

[21] Jensen JM, Schutze S, Forl M, Kronke M, Proksch E. Roles for tumor necrosis factor receptor p55 and sphingomyelinase in repairing the cutaneous permeability barrier. J Clin Invest 1999; 104(12): 1761-70.

[22] Brandner JM, Kief S, Wladykowski E, Houdek P, Moll I. Tight junction proteins in the skin. Skin Pharmacol Physiol 2006; 19(2): 71-7.

[23] Brandner JM, Kief S, Grund C, et al. Organization and formation of the tight junction system in human epidermis and cultured keratinocytes. Eur J Cell Biol 2002; 81(5): 253-63.

[24] Hanley K, Jiang Y, Katagiri C, Feingold KR, Williams ML. Epidermal steroid sulfatase and cholesterol sulfotransferase are regulated during late gestation in the fetal rat. J Invest Dermatol 1997; 108(6): 871-5.

[25] Hardman MJ, Sisi P, Banbury DN, Byrne C. Patterned acquisition of skin barrier function during development. Development (Cambridge, England) 1998; 125(8): 1541-52.

[26] Green M, Carol B, Behrendt H. Physiologic skin pH patterns in infants of low birth weight. The onset of surface acidification. Am J Dis Child 1968; 115(1): 9-16.

[27] Yosipovitch G, Maayan-Metzger A, Merlob P, Sirota L. Skin barrier properties in different body areas in neonates. Pediatrics 2000; 106(1 Pt 1): 105-8.

[28] Behrendt H, Green M. Skin $\mathrm{pH}$ pattern in the newborn infant. AMA 1958; 95(1, Part 1): 35-41.

[29] Fluhr JW, Mao-Qiang M, Brown BE, et al. Functional consequences of a neutral $\mathrm{pH}$ in neonatal rat stratum corneum. $\mathrm{J}$ Invest Dermatol 2004; 123(1): 140-51.

[30] Turner NG, Cullander C, Guy RH. Determination of the $\mathrm{pH}$ gradient across the stratum corneum. J Invest Dermatol Symp Proc/ Soc Invest Dermatol 1998; 3(2): 110-3.

[31] Visscher MO, Chatterjee R, Munson KA, Pickens WL, Hoath SB Changes in diapered and nondiapered infant skin over the first month of life. Pediatr Dermatol 2000; 17(1): 45-51.

[32] Behne MJ, Barry NP, Hanson KM, et al. Neonatal development of the stratum corneum $\mathrm{pH}$ gradient: localization and mechanisms leading to emergence of optimal barrier function. J Invest Dermatol 2003; 120(6): 998-1006.

[33] Charles RP, Guitard M, Leyvraz C, et al. Postnatal requirement of the epithelial sodium channel for maintenance of epidermal barrier function. J Biol Chem 2008; 283(5): 2622-30.

[34] Behne MJ, Meyer JW, Hanson KM, et al. NHE1 regulates the stratum corneum permeability barrier homeostasis. Microenvironment acidification assessed with fluorescence lifetime imaging. J Biol Chem 2002; 277(49): 47399-406.

[35] Holleran WM, Takagi Y, Imokawa G, Jackson S, Lee JM, Elias PM. beta-Glucocerebrosidase activity in murine epidermis: 
characterization and localization in relation to differentiation. $\mathrm{J}$ Lipid Res 1992; 33(8): 1201-9.

[36] Fluhr JW, Behne MJ, Brown BE, et al. Stratum corneum acidification in neonatal skin: secretory phospholipase A2 and the sodium/hydrogen antiporter-1 acidify neonatal rat stratum corneum. J Invest Dermatol 2004; 122(2): 320-9.

[37] Fluhr JW, Kao J, Jain M, Ahn SK, Feingold KR, Elias PM. Generation of free fatty acids from phospholipids regulates stratum corneum acidification and integrity. J Invest Dermatol 2001; 117(1): 44-51

[38] Turksen K, Troy TC. Overexpression of the calcium sensing receptor accelerates epidermal differentiation and permeability barrier formation in vivo. Mech Dev 2003; 120(6): 733-44.

[39] Ong PY, Leung DY. Immune dysregulation in atopic dermatitis. Curr Allergy Asthma Rep 2006; 6(5): 384-9.

[40] Fiset PO, Leung DY, Hamid Q. Immunopathology of atopic dermatitis. J Allergy Clin Immunol 2006; 118(1): 287-90.

[41] Proksch E, Folster-Holst R, Jensen JM. Skin barrier function, epidermal proliferation and differentiation in eczema. J Dermatol Sci 2006; 43(3): 159-69.

[42] Ruether A, Stoll M, Schwarz T, Schreiber S, Folster-Holst R. Filaggrin loss-of-function variant contributes to atopic dermatitis risk in the population of Northern Germany. Br J Dermatol 2006; 155(5): 1093-4.

[43] Palmer CN, Irvine AD, Terron-Kwiatkowski A, et al. Common loss-of-function variants of the epidermal barrier protein filaggrin are a major predisposing factor for atopic dermatitis. Nat Genet 2006; 38(4): 441-6.

[44] Motta S, Monti M, Sesana S, Mellesi L, Ghidoni R, Caputo R. Abnormality of water barrier function in psoriasis. Role of ceramide fractions. Arch Dermatol 1994; 130(4): 452-6.

[45] Nestle FO, Kaplan DH, Barker J. Psoriasis. N Engl J Med 2009; 361(5): 496-509.

[46] Smith FJ, Irvine AD, Terron-Kwiatkowski A, et al. Loss-offunction mutations in the gene encoding filaggrin cause ichthyosis vulgaris. Nat Genet 2006; 38(3): 337-42.

[47] Huber M, Rettler I, Bernasconi K, et al. Mutations of keratinocyte transglutaminase in lamellar ichthyosis. Science (New York, NY) 1995; 267(5197): 525-8

[48] Bouwstra JA, Honeywell-Nguyen PL, Gooris GS, Ponec M. Structure of the skin barrier and its modulation by vesicular formulations. Prog Lipid Res 2003; 42(1): 1-36.

[49] Lefevre C, Audebert S, Jobard F, et al. Mutations in the transporter ABCA12 are associated with lamellar ichthyosis type 2. Hum Mol Genet 2003; 12(18): 2369-78.

[50] Kelsell DP, Norgett EE, Unsworth H, et al. Mutations in ABCA12 underlie the severe congenital skin disease harlequin ichthyosis. Am J Hum Genet 2005; 76(5): 794-803.

[51] Howell MD, Kim BE, Gao P, et al. Cytokine modulation of atopic dermatitis filaggrin skin expression. J Allergy Clin Immunol 2007; 120(1): 150-5.

[52] Hammad H, Lambrecht BN. Dendritic cells and epithelial cells: linking innate and adaptive immunity in asthma. Nat Rev Immunol 2008; 8(3): 193-204.

[53] Hummler E, Vallon V. Lessons from mouse mutants of epithelial sodium channel and its regulatory proteins. J Am Soc Nephrol 2005; 16(11): 3160-6.

[54] Verrey F, Fakitsas P, Adam G, Staub O. Early transcriptional control of $\mathrm{ENaC}$ (de)ubiquitylation by aldosterone. Kidney Int 2008; 73(6): 691-6.

[55] Kellenberger S, Schild L. Epithelial sodium channel/degenerin family of ion channels: a variety of functions for a shared structure. Physiol Rev 2002; 82(3): 735-67.

[56] Waldmann R, Champigny G, Lazdunski M. Functional degenerincontaining chimeras identify residues essential for amiloridesensitive $\mathrm{Na}+$ channel function. J Biol Chem 1995; 270(20): 11735-7.

[57] Renard S, Lingueglia E, Voilley N, Lazdunski M, Barbry P. Biochemical analysis of the membrane topology of the amiloridesensitive Na+ channel. J Biol Chem 1994; 269(17): 12981-6.

[58] Canessa CM, Merillat AM, Rossier BC. Membrane topology of the epithelial sodium channel in intact cells. Am J Physiol 1994; 267(6 Pt 1): C1682-90.

[59] Eylam S, Spector AC. Oral amiloride treatment decreases taste sensitivity to sodium salts in $\mathrm{C} 57 \mathrm{BL} / 6 \mathrm{~J}$ and $\mathrm{DBA} / 2 \mathrm{~J}$ mice. Chem Senses 2003; 28(5): 447-58.
[60] Chandrashekar J, Kuhn C, Oka Y, et al. The cells and peripheral representation of sodium taste in mice. Nature 2010 Jan 27.

[61] Grunder S, Muller A, Ruppersberg JP. Developmental and cellular expression pattern of epithelial sodium channel alpha, beta and gamma subunits in the inner ear of the rat. Eur J Neurosci 2001; 13(4): 641-8.

[62] Mirshahi M, Nicolas C, Mirshahi S, Golestaneh N, d'Hermies F, Agarwal MK. Immunochemical analysis of the sodium channel in rodent and human eye. Exp Eye Res 1999; 69(1): 21-32.

[63] Ussing HH, Zerahn K. Active transport of sodium as the source of electric current in the short-circuited isolated frog skin. Acta Physiol Scand 1951; 23(2-3): 110-27.

[64] Cereijido M, Rotunno CA. Transport and distribution of sodium across frog skin. J Physiol 1967; 190(3): 481-97.

[65] Aceves J, Erlij D. Sodium transport across the isolated epithelium of the frog skin. J Physiol 1971; 212(1): 195-210.

[66] Barker AT, Jaffe LF, Vanable JW, Jr. The glabrous epidermis of cavies contains a powerful battery. Am J Physiol 1982; 242(3): R358-66.

[67] Denda M, Ashida Y, Inoue K, Kumazawa N. Skin surface electric potential induced by ion-flux through epidermal cell layers. Biochem Biophysl Res Comm 2001; 284(1): 112-7.

[68] Guitard M, Leyvraz C, Hummler E. A nonconventional look at ionic fluxes in the skin: lessons from genetically modified mice. News Physiol Sci 2004; 19: 75-9.

[69] Hummler E, Barker P, Gatzy J, et al. Early death due to defective neonatal lung liquid clearance in alpha-ENaC-deficient mice. Nat Genet 1996; 12(3): 325-8.

[70] McDonald FJ, Yang B, Hrstka RF, et al. Disruption of the beta subunit of the epithelial $\mathrm{Na}+$ channel in mice: hyperkalemia and neonatal death associated with a pseudohypoaldosteronism phenotype. Proc Natl Acad Sci USA 1999; 96(4): 1727-31.

[71] Barker PM, Nguyen MS, Gatzy JT, et al. Role of gammaENaC subunit in lung liquid clearance and electrolyte balance in newborn mice. Insights into perinatal adaptation and pseudohypoaldosteronism. J Clin Invest 1998; 102(8): 1634-40.

[72] Bonny O, Hummler E. Dysfunction of epithelial sodium transport: from human to mouse. Kidney Int 2000; 57(4): 1313-8.

[73] Rubera I, Loffing J, Palmer LG, et al. Collecting duct-specific gene inactivation of alphaENaC in the mouse kidney does not impair sodium and potassium balance. J Clin Invest 2003; 112(4): 554-65.

[74] Pradervand S, Vandewalle A, Bens M, et al. Dysfunction of the epithelial sodium channel expressed in the kidney of a mouse model for Liddle syndrome. J Am Soc Nephrol 2003; 14(9): 221928.

[75] Hummler E. Epithelial sodium channel, salt intake, and hypertension. Curr Hypertens Rep 2003; 5(1): 11-8.

[76] Roudier-Pujol C, Rochat A, Escoubet B, et al. Differential expression of epithelial sodium channel subunit mRNAs in rat skin. J Cell Sci 1996; 109 (Pt 2): 379-85.

[77] Oda Y, Imanzahrai A, Kwong A, et al. Epithelial sodium channels are upregulated during epidermal differentiation. J Invest Dermatol 1999; 113(5): 796-801.

[78] Brouard M, Casado M, Djelidi S, Barrandon Y, Farman N. Epithelial sodium channel in human epidermal keratinocytes: expression of its subunits and relation to sodium transport and differentiation. J Cell Sci 1999; 112 (Pt 19): 3343-52.

[79] Mauro T, Guitard M, Behne M, et al. The ENaC channel is required for normal epidermal differentiation. $\mathrm{J}$ Invest Dermatol 2002; 118(4): 589-94.

[80] Mauro T, Dixon DB, Komuves L, Hanley K, Pappone PA. Keratinocyte $\mathrm{K}+$ channels mediate $\mathrm{Ca} 2+$-induced differentiation. J Invest Dermatol 1997;108(6): 864-70.

[81] Menon GK, Grayson S, Elias PM. Ionic calcium reservoirs in mammalian epidermis: ultrastructural localization by ion-capture cytochemistry. J Invest Dermatol 1985; 84(6): 508-12.

[82] Komuves L, Oda Y, Tu CL, et al. Epidermal expression of the fulllength extracellular calcium-sensing receptor is required for normal keratinocyte differentiation. J Cell Physiol 2002; 192(1): 45-54.

[83] Ma HP, Saxena S, Warnock DG. Anionic phospholipids regulate native and expressed epithelial sodium channel (ENaC). J Biol Chem 2002; 277(10): 7641-4.

[84] Hara M, Ma T, Verkman AS. Selectively reduced glycerol in skin of aquaporin-3-deficient mice may account for impaired skin hydration, elasticity, and barrier recovery. J Biol Chem 2002; 277(48): 46616-21. 
[85] Rossier BC, Pradervand S, Schild L, Hummler E. Epithelial sodium channel and the control of sodium balance: interaction between genetic and environmental factors. Annu Rev Physiol 2002; 64: 877-97.

[86] Vallet V, Chraibi A, Gaeggeler HP, Horisberger JD, Rossier BC. An epithelial serine protease activates the amiloride-sensitive sodium channel. Nature 1997; 389(6651): 607-10.

[87] Vuagniaux G, Vallet V, Jaeger NF, et al. Activation of the amiloride-sensitive epithelial sodium channel by the serine protease mCAP1 expressed in a mouse cortical collecting duct cell line. J Am Soc Nephrol 2000; 11(5): 828-34.

[88] Shipway A, Danahay H, Williams JA, Tully DC, Backes BJ, Harris JL. Biochemical characterization of prostasin, a channel activating protease. Biochem Biophys Res Commun 2004; 324(2): 953-63.

[89] Andreasen D, Vuagniaux G, Fowler-Jaeger N, Hummler E, Rossier BC. Activation of Epithelial Sodium Channels by Mouse Channel Activating Proteases (mCAP) Expressed in Xenopus Oocytes Requires Catalytic Activity of mCAP3 and mCAP2 but not mCAP1. J Am Soc Nephrol 2006, 2006; 17(4): 968-76.

[90] Wang C, Chao J, Chao L. Adenovirus-mediated human prostasin gene delivery is linked to increased aldosterone production and hypertension in rats. Am J Physiol 2003; 284(4): R1031-6.

[91] Narikiyo T, Kitamura K, Adachi M, et al. Regulation of prostasin by aldosterone in the kidney. J Clin Invest 2002; 109(3): 401-8.

[92] Olivieri O, Castagna A, Guarini P, et al. Urinary prostasin: a candidate marker of epithelial sodium channel activation in humans. Hypertension 2005; 46(4):683-8.

[93] Donaldson SH, Hirsh A, Li DC, et al. Regulation of the epithelial sodium channel by serine proteases in human airways. J Biol Chem 2002; 277(10): 8338-45.

[94] Tong Z, Illek B, Bhagwandin VJ, Verghese GM, Caughey GH. Prostasin, a membrane-anchored serine peptidase, regulates sodium currents in JME/CF15 cells, a cystic fibrosis airway epithelial cell line. Am J Physiol Lung Cell Mol Physiol 2004; 287(5): L928-35.

[95] Satoru Takahashi SS, Shingo Inaguma, Yoshihisa Ikeda, et al. Down-regulated expression of prostasin in high-grade or hormonerefractory human prostate cancers. Prostate 2003; 54(3): 187-93.

[96] Chen LM, Chai KX. Prostasin serine protease inhibits breast cancer invasiveness and is transcriptionally regulated by promoter DNA methylation. Int J Cancer 2002; 97(3): 323-9.

[97] Sakashita K, Mimori K, Tanaka F, et al. Clinical significance of low expression of Prostasin mRNA in human gastric cancer. Eur J Surg Oncol 2008; 98(7): 559-64.

[98] Chen LM, Hodge GB, Guarda LA, Welch JL, Greenberg NM, Chai KX. Down-regulation of prostasin serine protease: a potential invasion suppressor in prostate cancer. Prostate 2001; 48(2): 93103.

[99] Mok SC, Chao J, Skates S, et al. Prostasin, a Potential Serum Marker for Ovarian Cancer: Identification Through Microarray Technology. J Natl Cancer Inst 2001; 93(19): 1458-64.

[100] Carattino MD, Hughey RP, Kleyman TR. Proteolytic processing of the epithelial sodium channel \{gamma\} subunit has a dominant role in channel activation. J Biol Chem 2008; 283(37): 25290-5.

[101] Rubera I, Meier E, Vuagniaux G, et al. A conditional allele at the mouse channel activating protease 1 (Prss8) gene locus. Genesis 2002; 32(2): 173-6.

[102] Li M, Chiba H, Warot X, et al. RXR-alpha ablation in skin keratinocytes results in alopecia and epidermal alterations. Development (Cambridge, England) 2001; 128(5): 675-88.

[103] Wallrapp C, Hahnel S, Muller-Pillasch F, et al. A novel transmembrane serine protease (TMPRSS3) overexpressed in pancreatic cancer. Cancer Res 2000; 60(10): 2602-6.

[104] Garcia-Caballero A, Dang Y, He H, Stutts MJ. ENaC proteolytic regulation by channel-activating protease 2. J Gen Physiol 2008; 132(5): 521-35.

[105] Jung H, Lee KP, Park SJ, et al. TMPRSS4 promotes invasion, migration and metastasis of human tumor cells by facilitating an epithelial-mesenchymal transition. Oncogene 2008; 27(18): 263547.

[106] Kim MG, Chen C, Lyu MS, et al. Cloning and chromosomal mapping of a gene isolated from thymic stromal cells encoding a new mouse type II membrane serine protease, epithin, containing four LDL receptor modules and two CUB domains. Immunogenetics 1999; 49(5): 420-8.

[107] Takeuchi T, Shuman MA, Craik CS. Reverse biochemistry: use of macromolecular protease inhibitors to dissect complex biological processes and identify a membrane-type serine protease in epithelial cancer and normal tissue. Proc Natl Acad Sci USA 1999; 96(20): 11054-61.

[108] Lin CY, Anders J, Johnson M, Sang QA, Dickson RB. Molecular cloning of cDNA for matriptase, a matrix-degrading serine protease with trypsin-like activity. J Biol Chem1999; 274(26): 18231-6.

[109] List K, Szabo R, Wertz PW, et al. Loss of proteolytically processed filaggrin caused by epidermal deletion of Matriptase/MT-SP1. J Cell Biol 2003; 163(4):901-10.

[110] Netzel-Arnett S, Currie BM, Szabo R, et al. Evidence for a matriptase-prostasin proteolytic cascade regulating terminal epidermal differentiation. J Biol Chem 2006; 281(44): 32941-5.

[111] Basel-Vanagaite L, Attia R, Ishida-Yamamoto A, et al. Autosomal recessive ichthyosis with hypotrichosis caused by a mutation in ST14, encoding type II transmembrane serine protease matriptase. Am J Hum Genet 2007; 80(3): 467-77.

[112] Scharschmidt TC, List K, Grice EA, et al. Matriptase-Deficient Mice Exhibit Ichthyotic Skin with a Selective Shift in Skin Microbiota. J Invest Dermatol 2009; 129: 2435-42.

[113] Takeuchi T, Harris JL, Huang W, Yan KW, Coughlin SR, Craik CS. Cellular localization of membrane-type serine protease 1 and identification of protease-activated receptor-2 and single-chain urokinase-type plasminogen activator as substrates. J Biol Chem 2000; 275(34): 26333-42.

[114] Oberst M, Anders J, Xie B, et al. Matriptase and HAI-1 are expressed by normal and malignant epithelial cells in vitro and in vivo. Am J Pathol 2001; 158(4): 1301-11.

[115] Tanimoto H, Underwood LJ, Wang Y, Shigemasa K, Parmley TH, O'Brien TJ. Ovarian tumor cells express a transmembrane serine protease: a potential candidate for early diagnosis and therapeutic intervention. Tumour Biol 2001; 22(2): 104-14.

[116] Kang JY, Dolled-Filhart M, Ocal IT, et al. Tissue microarray analysis of hepatocyte growth factor/Met pathway components reveals a role for Met, matriptase, and hepatocyte growth factor activator inhibitor 1 in the progression of node-negative breast cancer. Cancer Res 2003; 63(5): 1101-5.

[117] List K, Szabo R, Molinolo A, et al. Deregulated matriptase causes ras-independent multistage carcinogenesis and promotes rasmediated malignant transformation. Genes Dev 2005; 19(16): 1934-50.

[118] Kataoka H, Suganuma T, Shimomura T, et al. Distribution of hepatocyte growth factor activator inhibitor type 1 (HAI-1) in human tissues. Cellular surface localization of HAI-1 in simple columnar epithelium and its modulated expression in injured and regenerative tissues. J Histochem Cytochem 1999; 47(5): 673-82.

[119] Kataoka H, Miyata S, Uchinokura S, Itoh H. Roles of hepatocyte growth factor (HGF) activator and HGF activator inhibitor in the pericellular activation of $\mathrm{HGF} / \mathrm{scatter}$ factor. Cancer Metastasis Rev 2003; 22(2-3): 223-36.

[120] Kataoka H, Shimomura T, Kawaguchi T, et al. Hepatocyte growth factor activator inhibitor type 1 is a specific cell surface binding protein of hepatocyte growth factor activator (HGFA) and regulates HGFA activity in the pericellular microenvironment. J Biol Chem 2000; 275(51): 40453-62.

[121] Kirchhofer D, Peek M, Lipari MT, Billeci K, Fan B, Moran P. Hepsin activates pro-hepatocyte growth factor and is inhibited by hepatocyte growth factor activator inhibitor-1B (HAI-1B) and HAI-2. FEBS Lett 2005; 579(9): 1945-50.

[122] Fan B, Wu TD, Li W, Kirchhofer D. Identification of hepatocyte growth factor activator inhibitor-1B as a potential physiological inhibitor of prostasin. J Biol Chem 2005; 280(41): 34513-20.

[123] List K, Bugge TH, Szabo R. Matriptase: potent proteolysis on the cell surface. Mol Med (Cambridge) 2006; 12(1-3): 1-7.

[124] Tanaka H, Nagaike K, Takeda N, et al. Hepatocyte growth factor activator inhibitor type 1 (HAI-1) is required for branching morphogenesis in the chorioallantoic placenta. Mol Cell Biol 2005; 25(13): 5687-98.

[125] Nagaike K, Kawaguchi M, Takeda N, et al. Defect of hepatocyte growth factor activator inhibitor type 1 /serine protease inhibitor, Kunitz type 1 (Hai-1/Spint1) leads to ichthyosis-like condition and abnormal hair development in mice. Am J Pathol 2008; 173(5): 1464-75.

[126] Picard N, Eladari D, El Moghrabi S, et al. Defective ENaC processing and function in tissue kallikrein-deficient mice. J Biol Chem 2008; 283(8): 4602-11. 
[127] Lundstrom A, Egelrud T. Stratum corneum chymotryptic enzyme: a proteinase which may be generally present in the stratum corneum and with a possible involvement in desquamation. Acta Dermato Venereol 1991; 71(6): 471-4.

[128] Brattsand M, Stefansson K, Lundh C, Haasum Y, Egelrud T. A proteolytic cascade of kallikreins in the stratum corneum. J Invest Dermatol 2005; 124(1): 198-203.

[129] Komatsu N, Tsai B, Sidiropoulos M, et al. Quantification of eight tissue kallikreins in the stratum corneum and sweat. J Invest Dermatol 2006; 126(4): 925-9.

[130] Komatsu N, Saijoh K, Toyama T, et al. Multiple tissue kallikrein mRNA and protein expression in normal skin and skin diseases. $\mathrm{Br}$ J Dermatol 2005; 153(2): 274-81.

[131] Borgono CA, Michael IP, Komatsu N, et al. A potential role for multiple tissue kallikrein serine proteases in epidermal desquamation. J Biol Chem 2007; 282(6): 3640-52.

[132] Hansson L, Backman A, Ny A, et al. Epidermal overexpression of stratum corneum chymotryptic enzyme in mice: a model for chronic itchy dermatitis. J Invest Dermatol 2002; 118(3): 444-9.

[133] Descargues P, Deraison C, Bonnart C, et al. Spink5-deficient mice mimic Netherton syndrome through degradation of desmoglein 1 by epidermal protease hyperactivity. Nat Genet 2005; 37(1): 56-65.
[134] Svenningsen P, Bistrup C, Friis UG, et al. Plasmin in nephrotic urine activates the epithelial sodium channel. J Am Soc Nephrol 2009; 20(2): 299-310

[135] Passero CJ, Mueller GM, Rondon-Berrios H, Tofovic SP, Hughey RP, Kleyman TR. Plasmin activates epithelial Na+ channels by cleaving the gamma subunit. J Biol Chem 2008; 283(52): 3658691.

[136] Rijken DC, Lijnen HR. New insights into the molecular mechanisms of the fibrinolytic system. J Thromb Haemost 2009; 7(1): 4-13.

[137] Moali C, Hulmes DJ. Extracellular and cell surface proteases in wound healing: new players are still emerging. Eur J Dermatol 2009; 19: 552-64.

[138] Voegeli R, Rawlings AV, Doppler S, Schreier T. Increased basal transepidermal water loss leads to elevation of some but not all stratum corneum serine proteases. Int J Cosmet Sci 2008; 30(6): 435-42.

[139] Ovaere P, Lippens S, Vandenabeele P, Declercq W. The emerging roles of serine protease cascades in the epidermis. Trends Biochem Sci 2009; 34(9): 453-63.

[140] Planes C, Randrianarison NH, Charles RP, et al. ENaC-mediated alveolar fluid clearance and lung fluid balance depend on the channel-activating protease 1. EMBO Mol Med 2010; 2(1): 26-37.

(C) Frateschi et al.; Licensee Bentham Open.

This is an open access article licensed under the terms of the Creative Commons Attribution Non-Commercial License (http://creativecommons.org/licenses/by-nc/ 3.0/) which permits unrestricted, non-commercial use, distribution and reproduction in any medium, provided the work is properly cited. 